\title{
Acquisition Work in College Libraries
}

\author{
Mr. Christ is assistant librarian, Duke \\ University.
}

$I^{x}$ THE recent survey, College and Univer1 sity Libraries and Librarianship, prepared by the College and University Postwar Planning Committee of the American Library Association and the Association of College and Reference Libraries, the following statement is made:

The actual procedures and routines for book buying, within the individual library, are in a good many cases, it is suspected, susceptible of simplification and streamlining. ... Every library might well examine or re-examine its order routines in an effort to cut down as much as possible that delay between the initiating of an order and the availability of the book for use, a delay that is with some justice more or less of a standing complaint of the average faculty member.... We may expect to see, and should encourage, much experimentation ... in quest of the simplest and most economical way to accomplish this important library function. ${ }^{2}$

Last winter the writer made such an "examination" of acquisition work in ten eastern college libraries to discover what procedures for the book purchasing are currently employed, what results are obtained, what routines may be designated as the most satisfactory, and what differentiation, if any, is made in college libraries between professional and nonprofessional functions of the acquisition department. The results of this investigation are reported in detail in an essay presented for the master's degree to

1 Paper presented at the College Libraries Section, A.C.R.L., June 16, 1948, Atlantic City, N.J.

2 Chicago, 1946. p. $39-40$. the School of Library Service at Columbia University. The essay goes one or two steps further than suggested in the above quotation and sets up, on the basis of current practices and results in the libraries studied, tentative standards by which the performance of the acquisition department of any college library may be evaluated, and suggests a purchasing procedure suitable for all libraries of this type.

This paper, which is based on the larger essay, summarizes some of the chief data collected. It touches briefly on the colleges and the libraries, the acquisition departments and their functions, and discusses in some detail the results obtained by the acquisition departments and the tentative performance standards. Material collected on procedures, records, forms, and similar factors is omitted.

The investigation was conducted by personal visits to ten college libraries, where the librarians and acquisition heads were interviewed, records and files examined, and the workings of the departments observed. The ten colleges are Connecticut College for Women, Trinity (Hartford), Bowdoin, Wesleyan University (Middletown), Williams, Amherst, Mount Holyoke, Vassar, Wellesley, and Smith. They are private, four-year liberal arts colleges, selected because they are sufficiently similar in curricula and objectives to have comparable library programs and similar acquisition problems and requirements. Yet there is a sufficiently wide variation in the size of the colleges, the libraries, and their budgets to make up a representative group of college 
libraries for the purposes of the study.

The colleges vary in number of students (1946-47 enrolment) from 837 to 2266 , not quite a 300 per cent variation. Their libraries vary in number of volumes from I I 7,866 to 338,323 , again about a 300 per cent variation. The library budgets run from $\$ 25,389$ to $\$ 98,807$, nearly a 400 per cent range, and the library staff from 6 to 29.5 persons. The acquisition budgets (i.e., books, periodicals, and binding), which ranged from $\$ 8,880$ to $\$ 27,323$, are allocated to departments of instruction and a librarian's general fund in six of the libraries. In all the libraries the chief source of recommendations for purchase is the faculty and the librarian.

The acquisition departments in these libraries vary from one-half to three and one-half persons or the equivalents. Three have a library school graduate giving full time to acquisition work, and two more have a library school graduate giving half time. In all the libraries the facilities for the acquisition department were adequate, that is, adequate space and suitable location, typewriters, adding machines, and bibliographical collections. Several have superior facilities of this sort. Only four, however, have an acquisition department manual in any form, which suggests that the others place rather unreasonable reliance on there being no sudden personnel changes.

The investigation showed that normally the acquisition department of the college library does the purchasing of all types of materials: books, continuations, periodicals, documents, maps, etc. Only three libraries have a separate serials department which takes care of periodical subscriptions. These libraries are the three largest in size of collection, the sixth, seventh, and tenth in size of library staff, and the sixth, eighth, and tenth in total expenditure for acquisitions. One of them has a documents department as well, which handles all ordering and receiving of federal and state documents. The solicitation and disposition of gifts is in all cases handled outside the acquisition department, usually by the librarian, but searching and processing is customarily done by the department as for purchases. The same would be true of exchanges, except that all but two of the libraries reported that because of increased service demands without corresponding increase in staff, they were not doing enough exchange work to record it as part of the acquisition department's work load. In none of the libraries does the department have a specific responsibility for the selection of titles, although three of them may make the decision on the edition to be purchased, and only one routes publishers' announcements and dealers' catalogs.

The preparation of bills for payment, bookkeeping, and budgetary control are the responsibility of the acquisition department except at one library where an executive secretary keeps all financial records. In all but one library the department prepares slips for Library of Congress card orders, though frequently the slips are turned over to the catalog department to send. In the single exception, the catalog department prepares and sends the card orders after a daily examination of outgoing book orders. At two libraries, the acquisition department receives the cards and matches them with the books on receipt.

In addition to this regularity of function, a variety of other responsibilities is assigned to the acquisition department in almost all the libraries. In some cases this is doubtless because of the nature of the activity, such as the preparation and distribution of an accessions list, or the ordering of all library supplies and the distribution and maintenance of stock. In other cases, primarily in libraries with small staffs, this is probably 
more a matter of convenience and available personnel, and such duties as the operation of a special textbook library, maintenance of the accessions register, service as the librarian's secretary or administrative assistant, or the preparation of materials for binding, fall to the lot of the acquisition department.

\section{Criteria for Measurement}

To measure the results obtained and to judge the quality of service (in 1946-47) several factors, all capable of exact statistical recording, were selected. Principal among these are the following:

I. Time lags

a. From receipt of recommendation to placing of order

b. From placing of order to receipt of book

c. From receipt of book to completion of acquisition process

2. Discounts received (on current domestic publications)

3. Bibliographical accuracy

a. Number of unintentional duplicates received

b. Number of incorrect items received

c. Number of items rejected by dealers as not identifiable

4. Percentage of successful orders from dealers' catalogs

5. Number of titles and volumes purchased and otherwise processed

6. Expenditure for books

The investigation showed that it would be impossible to make a wholly valid evaluation of the performance of the acquisition departments, partly because of the variation in functions performed, but primarily because reliable statistics are not available for most of the test factors. College library administrators have shown regrettably little interest in testing the efficiency of their acquisition departments, and as a result no statistical records of work performed by the departments, even for test periods, are main- tained. The discounts currently received on domestic publications were available from all libraries, though even here it was necessary actually to examine invoices to secure these figures in some instances. No library had any record of the number of unintentional duplicates received in the course of a year, the number of incorrect items supplied, or the number of items rejected by the dealers. It was only the investigator's persistence which brought forth even estimates for these factors. The same is true of the percentage of successful orders from dealers' catalogs, although every title ordered and not secured represents an actual loss to the library in time spent on searching, preparation of orders, and maintaining records.

Time lags within the acquisition department and in the supplying of books ordered were in all cases only estimates, though made with less reluctance and more confidence than the estimates on factors mentioned above. Since only three libraries count books as they are received in the acquisition department, this factor had generally to be recorded on the basis of the count of books cataloged. Although the number of titles is more significant in relation to work load in both acquisition and catalog departments, the majority of the libraries could supply only the number of volumes. Two of the libraries do not keep financial records in sufficient detail to have readily available the total expenditure for books only, but lump books and periodicals. A third has no available breakdown beyond the total expenditure for acquisitions: books, periodicals, and binding. With these very considerable limitations in mind, however, it is possible to make some general observations on the performance and quality of service of the acquisition departments in college libraries as exemplified by this sample group. 
For time lags, all but one of the libraries made a point of sending rush orders within one day of the receipt of requests. For normal requests, three libraries ordered once a week, and one only once every two weeks (with foreign orders sent monthly). The average time for the others was about three days. For very small purchasing operations, weekly orders are perhaps economical of staff time since there are real savings in performing certain routines on a number of titles at one time, though it is doubtful whether such a practice can be defended in terms of service to users.

The time required to receive books (domestic, in print) after placing the orders was estimated by most libraries as from fourteen days up. One library, however, said it seldom received books in less than three weeks, another in less than four weeks. At one library, which estimated fourteen days as the average time lag between the ordering and receipt of books, an analysis of all orders placed for current domestic publications between September 15 and Oct. 15,1947 , and filled prior to December 28, was made on that date.

Fifty-six per cent of rush requests had been ordered within one day, and 12 per cent more within two or three days. (The remaining 32 per cent did not show the date the request was received.) Among normal requests, of which 13.4 per cent did not show the date of receipt, 63 per cent were ordered within one day, and another 20.2 per cent within two or three days. Combining the two types of orders, 80.5 per cent of all requests were ordered within three days, which verified this library's estimate of this time lag.

The same library's estimate of fourteen days from the placing of an order to the receipt of the book was proved, however, to be far from reliable. Of rush orders, only 28 per cent were received within two weeks, and 25.2 per cent of normal orders in the same time. The next week brought 40 per cent more of the rush books but only 20.2 per cent of normal orders. In four weeks, 72 per cent of rush items and 56.3 per cent of normal orders, or only 59 per cent of all orders were received. Of all orders filled for current domestic publications, only 79.8 per cent had been supplied in six weeks, and the remaining 20.2 per cent required more than six weeks and up to IO3 days (i.e., the total time from September 15 to December 28 , the day analysis was made). But in addition to the 144 books ordered and received, within this period, 14 additional titles (including one rush item) were ordered and had not been received or reported on. Two more (including one rush) were ordered and incorrect items supplied, the corrections not having been completed. Thus of 160 titles actually ordered in the test period of one month, 115 or 71.9 per cent were received within 42 days; 29 more or 18.1 per cent were received within $43-\mathrm{IO} 3$ days; and 16 titles or Io per cent required an indeterminate longer period. If the error in estimating was comparable in other libraries, there is validity in the suggestion made in the quotation with which this paper opened.

At one library, where the librarian felt confident of his estimate of a two-week delay from the ordering of a book to its receipt, a number of filled-order cards were examined at random and bore out the assertion that it was exceptional for there to be a longer time lag. A detailed analysis such as described above could not, however, be made at this library.

Most of the departments completed their records and moved books on for cataloging in not more than two days. In most cases, invoices are received at the same time or before the books. One library never waits for an invoice (in fact, checks in its books 
without the invoice even though it has been received), two always wait for invoices, although at one of them the invoices are not infrequently received as much as two weeks after the books, which is a considerable delay. (Since this investigation was made, this library has revised its procedure and no longer holds books for invoices.)

The study of discounts received on current domestic publications by libraries in this group showed a range from low to high of 10 to 40 per cent, but the concentration was heavy at 25 to 30 per cent on trade titles and ro per cent on short discount items. The highest discount was related to slow service, and the lowest to fast service, proving once again (perhaps) that one gets what one pays for.

Under bibliographical accuracy, the estimates for the number of unintentional duplicates received ranged from 6 to 15 , with concentration at 10 to 12 . In proportion as this number is reduced, without loss in other factors of service, the department's efficiency may be considered to be increased. Three libraries had no recollection of incorrect titles supplied, but the others estimated from 5 to 36 , or approximately two to six per thousand volumes purchased. These may result from errors on the part of the dealer, or of the department in preparing orders and supplying bibliographical details. Wherever the responsibility lies, such errors are costly to both parties in time required to make corrections. Five libraries had no recollection of titles which their dealers had rejected as not identifiable or because they required bibliographical corrections or additions. The other five estimated from two to twelve a year.

The most common statement concerning the percentage of successful orders from dealers' catalogs was, "we lose a lot." When pressed for an estimate, the libraries' replies varied from 25 to 75 per cent, half of them estimating 50 per cent. The library where the time lag estimates were checked as described above estimated that it received 50 per cent of all orders from dealers' catalogs. To verify this, all such orders placed from July I to Nov. 30, 1947, were checked. (This was done on December 28 , when it was assumed that all successful orders would have been received.) Of 136 items ordered in this period, 85 were received. This represents 62.5 per cent success on this type of order.

The following table gives a picture of the acquisition departments' performance in the ten libraries in terms of the amount spent for books, the number of volumes purchased, and the size of the staff. It shows also certain other factors affecting the work loads of the departments. The apparent net cost, figured simply by divid. ing the expenditure for books by the number of volumes purchased, is included as a matter of interest. The variations and vagaries of library accounting and statistical procedures are so well known that it is unnecessary to do more than point out that this cost may at best be considered only a rough estimate.

Any attempt to select from such records the most efficient acquisition department must take all of these factors into account, along with other data (not included here) showing the forms used and records kept at each library, the actual purchasing procedures followed, the complete list of functions performed. It might appear that library III has the best performance record, since only half the time of one person was required to spend $\$ 8564$ for 2839 volumes at approximately $\$ 3.02$ each, and in addition to handle I 968 gift volumes, library bookkeeping, and periodical purchasing. But this library does not have a departmentalized allocation of its book funds. Therefore its 
Table I

Acquisition Department Performance, 1946-47

\begin{tabular}{|c|c|c|c|c|c|c|c|c|c|c|c|}
\hline \multirow[b]{2}{*}{ 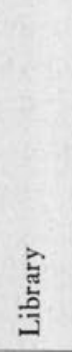 } & \multirow[b]{2}{*}{ 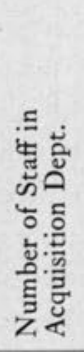 } & \multirow[b]{2}{*}{ 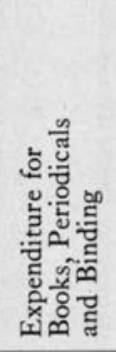 } & \multicolumn{3}{|c|}{ Book Purchasing } & \multicolumn{6}{|c|}{$\begin{array}{l}\text { Principal Other Functions } \\
\text { Affecting Work Load }\end{array}$} \\
\hline & & & 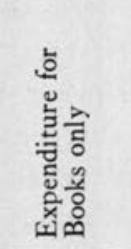 & 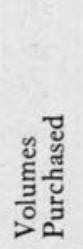 & 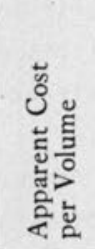 & 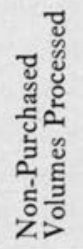 & 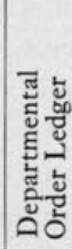 & 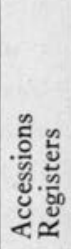 & 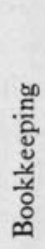 & 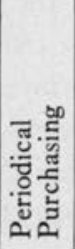 & 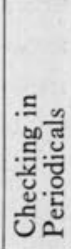 \\
\hline I & 2 & $\$ 16,434$ & $\$ 12,357$ & 2923 & $\$ 4.23$ & 1179 & $\mathrm{x}$ & & $\mathrm{x}$ & $\mathrm{x}$ & \\
\hline II & 2 & 8880 & $8 \mathrm{cta}^{\mathrm{b}}$ & 1988 & & 4476 & & $\mathrm{x}$ & $\mathrm{x}$ & $\mathrm{x}$ & $\mathrm{x}$ \\
\hline IV & $2^{\mathrm{a}^{5^{\mathrm{n}}}}$ & $\begin{array}{l}13,273 \\
19,008\end{array}$ & $\begin{array}{l}8564 \\
6020\end{array}$ & $\begin{array}{l}2839 \\
1636^{t}\end{array}$ & $\begin{array}{l}3.02 \\
3.44^{\circ}\end{array}$ & $\begin{array}{l}1968 \\
6303\end{array}$ & & & $\begin{array}{l}x \\
x\end{array}$ & $\mathrm{x}$ & \\
\hline V & I & 16,842 & 9996 & 2267 & $\begin{array}{l}3.44 \\
4.4 \mathrm{I}\end{array}$ & $48 \mathrm{I}$ & & & $\hat{x}$ & $\mathrm{x}$ & \\
\hline VI & 2.5 & 23,117 & $15,66_{2}$ & 6238 & 2.53 & $153 \mathrm{I}$ & 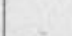 & & & & \\
\hline VII & 2 & 16,139 & 10,404 & 3130 & $3 \cdot 32$ & 1564 & & & $\mathrm{x}$ & $\mathrm{x}$ & $x^{g}$ \\
\hline VIII & $3 \cdot 5$ & 22,229 & & 3223 & & 1398 & & & $\mathrm{x}$ & $\mathrm{x}$ & \\
\hline IX & $3 \cdot 5$ & 27,323 & 16,994 & 6107 & 2.78 & 1383 & $\mathrm{x}$ & & $\mathrm{x}$ & $\mathrm{x}$ & \\
\hline $\mathrm{X}$ & 2.5 & 26,066 & & $785^{2}$ & & & $\mathrm{x}$ & & $\mathrm{x}$ & & \\
\hline
\end{tabular}

a Estimated full-time equivalent.

bot available; for books and periodicals, $\$ 7446$.

¿ From the librarian's annual report.

Not available; for books and periodicals, $\$ 17,875$.

e Not available.

$i$ Does not include 1140 volumes by purchases on bloc; this is the number $\left(16{ }_{3} 6\right)$ for which individual orders were placed.

g New assignment in $1947-48$, but a corresponding amount of time was spent in $1946-47$ on other work outside the Acquisition Department.

bookkeeping is greatly simplified. Its expenditure for periodicals and binding was only $\$ 4709$, which means its periodical list was relatively small. The acquisition department does not order Library of Congress cards or prepare any other process slips or records for purchases or gifts, keeps no permanent purchase record, and has no follow-up routine.

At library IX, the acquisition department has 3.5 persons and spent only twice as much for books $(\$ 16,994)$, securing more than twice as many volumes $\left(6 \mathrm{IO}_{10}\right)$ at about $\$ 2.78$ per volume, but handled fewer nonpurchased items ( $\left.\mathrm{I}_{383}\right)$. On the other hand, it too does the library bookkeeping, with a departmentalized budget, and keeps a departmental order ledger as well. Like library III, it handles the purchasing of periodicals, and with an expenditure of $\$ 10,329$ for periodicals and binding it must have a large subscription list. Moreover, it prepares L.C. card order slips, routes publishers' announcements and dealers' catalogs, and has an aggressive follow-up routine.

Library VI had 2.5 persons who spent almost as much for books as at library IX $(\$ 15,662$ as compared with $\$ 16,994)$ but secured a few more volumes $(6238)$ at an average cost of $\$ 2.53$, and handled $153 \mathrm{I}$ gifts. The department does not do the bookkeeping or periodical purchasing. It does supply a permanent purchase record on shelflist cards, types every request onto a specially designed card which makes possi. ble quick preparation of a departmentalized statement of orders outstanding or orders filled, and returns all request cards to the requesters with notice of action taken.

\section{Tentative Standard}

Thus while the data presented here on current practices and results in the acquisi- 
tion departments of ten college libraries are untrustworthy for purposes of comparison of any two or more libraries within the group, they do provide a guide to a tentative standard for staff, function and performance of acquisition departments in libraries of this type. To conform to this standard, the acquisition department of a college library should purchase and receive all books and continuations, purchase all periodicals, and process all gifts. In doing so, it should prepare Library of Congress card orders, temporary catalog cards, and notifications of receipt to be sent to requesters. It should provide a means to determine outstanding orders and amounts spent (both total and by department or other fund), and a permanent purchase record for each title acquired. It should prepare the library's bills for payment, and do whatever bookkeeping is dictated by the library's own needs. It should place orders within one day for rush books and for all others within three days of receipt of requests, and complete its own checks and records within two days after the books are received, which should be from two to four weeks after the orders are placed (domestic). All titles not supplied should be promptly and persistently followed up. On domestic publications it should secure discounts not lower than 25 per cent for trade titles and ro per cent for short discount items, although the institution may elect to accept lower discounts in favor of prompt and accurate service. It should receive not more than two unintentional duplicates nor three incorrect titles per thousand books ordered, and titles rejected by the dealer as not identifiable should not exceed one per thousand. It should obtain at least 50 per cent success in purchasing from the catalogs of American secondhand or rare book dealers.

To accomplish the above, the acquisition department will have a staff related in size to the total expenditure for acquisitions (with a normal allocation therefrom for books alone) and to the number of volumes purchased. This relationship is shown in Table II, which should be read as follows: a college library spending approximately $\$ \mathrm{IO}, 000$ for acquisitions and up to $\$ 7500$ of this for books will be able to purchase about 2000 volumes and will need one person to handle acquisition work. Or, a college library spending $\$ 10,000$ to $\$ I_{5}, 000$ for acquisitions will probably use $\$ 7500$ to $\$ 10,000$ of this for books, will purchase from 2000 to 3000 volumes, and will need I. 5 persons to handle all acquisition work.

Where the staff is one, it will not be a trained librarian, and supervision will be exercised by the head librarian. Where the staff is from 1.5 to three persons, at least half-time service will be a trained librarian and the department will operate independently under general policies established by the head librarian. Where the staff has four full-time members, one will be a trained librarian and the department will function as an independent unit.

Table II

Tentative Standards for the Acquisition Department of a College Library Based Upon Current Practices in Ten College Libraries

\begin{tabular}{|c|c|c|c|}
\hline $\begin{array}{l}\text { Expenditure for } \\
\text { Acquisitions }\end{array}$ & $\begin{array}{l}\text { Probable Expenditure } \\
\text { for Books Only }\end{array}$ & $\begin{array}{l}\text { Probable Number of } \\
\text { Volumes Purchased }\end{array}$ & Staff \\
\hline $10, \infty 00$ & $\$ \quad-7500$ & -2000 & I \\
\hline $10, \infty 00-15, \infty 00$ & $7500-10,000$ & $2000-3000$ & I. 5 \\
\hline I $5, \infty 00-20, \infty$ & 10, $, 00-13,500$ & $3000-4000$ & 2 \\
\hline $20, \infty \infty-25, \infty \infty$ & $13,500-16,500$ & $4000-6000$ & 3 \\
\hline $25, \infty \infty-30, \infty \infty$ & $16,500-19,000$ & $6000-7500$ & 4 \\
\hline
\end{tabular}

